\title{
The Value of International Law in Combating Transnational Organized Crime in the Asia-Pacific
}

\author{
Tom OBOKATA* \\ Keele University, United Kingdom \\ t.obokata@keele.ac.uk
}

\begin{abstract}
This paper explores the value of international law in combating transnational organized crime in the Asia-Pacific, with particular reference to the United Nations Convention against Transnational Organized Crime. It begins by highlighting the definitions of organized crime under national and international law. It then analyzes the extent to which states in the Asia-Pacific have implemented the Convention, focusing on harmonization of national criminal laws and procedures, mutual recognition of law enforcement decisions and measures, as well as provision of technical assistance. The paper also touches upon the protection of the human rights of victims and perpetrators of organized crime. The main conclusion reached is that, although the implementation of international instruments pertinent to transnational organized crime has not been an easy task in the Asia-Pacific, they are slowly but surely making a difference on the ground. Therefore, their value should not be dismissed completely.
\end{abstract}

The Asia-Pacific region ${ }^{\mathrm{I}}$ is deeply affected by transnational organized crime. Major crimes prevalent in the region include drug offences, trafficking in human beings, counterfeit goods, medicines, wildlife, ${ }^{2}$ as well as timber. ${ }^{3}$ The annual profits generated from these criminal activities are estimated to be around \$9o billion in the Asia-Pacific alone, which corresponds to "twice the GDP of Myanmar, eight times that of Cambodia, and thirteen times that of Lao PDR". "Unlike ordinary crime, organized crime flourishes because of the supply/demand dynamics. Illegal production and

\footnotetext{
* Professor of International Law and Human Rights, School of Law, Keele University, United Kingdom.

I. Acknowledging that there is no precise definition of "Asia-Pacific", this paper examines state practice in East Asia (e.g. China, Japan, and the Republic of Korea), South Asia (e.g. India, Nepal, and Pakistan), Southeast Asia (e.g. Malaysia, the Philippines, and Thailand), and Oceania (e.g. Australia, Fiji, and New Zealand).

2. United Nations Office of Drugs and Crime (UNODC), Transnational Organized Crime in East Asia and the Pacific: A Threat Assessment (Vienna: UNODC, 20I3) at Executive Summary.

3. Andreas SCHLOENHARDT, "The Illegal Trade in Timber and Timber Products in the Asia-Pacific", Australian Institute of Criminology, Research and Policy Series No. 89, 2008.

4. UNODC, supra note 2 at $\mathrm{I}$.
} 
trafficking of goods, services, and human beings will continue as long as there is a strong demand for them within and outside of the Asia-Pacific. There is, for instance, strong demand for commercial sex in Southeast Asia, and sex workers have been trafficked to meet such demand. ${ }^{5}$ Of particular concern is child sex tourism, which is prevalent in the Mekong Sub-region. ${ }^{6}$ Some forms of organized crime, such as migrant smuggling and human trafficking, are carried out by those known to victims (e.g. relatives, friends, and other acquaintances), ${ }^{7}$ but more sophisticated criminal groups, including triads based in Hong Kong, yakuza in Japan, as well as Iranian, Pakistani, and Nigerian syndicates, are actively involved in drug-related offences, among others. ${ }^{8}$

While each state is responsible for combating organized crime at the national level, its transnational nature means that domestic efforts alone are not sufficient, and that closer and more effective international co-operation is necessary. Given the diversity in domestic criminal laws and procedures, however, this is not an easy task. In the Asia-Pacific region, for instance, a number of states ${ }^{9}$ are based on the common-law tradition, while others ${ }^{\mathrm{IO}}$ are strongly influenced by the civil-law tradition. Such a distinction cannot be drawn in many cases, as various states are also influenced by other factors such as religion and local customs, ${ }^{\text {II }}$ or are based on hybrid systems. ${ }^{\text {I } 2}$ The international community has been taking various steps to bridge these differences, the most significant one being the adoption of the United Nations Convention against Transnational Organized Crime ${ }^{\mathrm{I} 3}$ (UNTOC) in 2000. This treaty is extremely important as it encourages states to implement more effective action against transnational organized crime, not only through the enhancement of domestic criminal laws and procedures, but also through the promotion of international law enforcement

5. Susan KNEEBONE and Julie DEBELJAK, Transnational Crime and Human Rights: Responses to Human Trafficking in the Greater Mekong Subregion (Abingdon: Routledge, 201 2).

6. ECPAT International, Combating Child Sex Tourism (Bangkok: ECPAT International, 2008); Kelly COTTER, "Combating Child Sex Tourism in Southeast Asia" (2009) 37 Denver Journal of International Law and Policy 493; Afrooz K. JOHNSON, "International Child Sex Tourism: Enhancing the Legal Response in South-East Asia" (2OII) I9 International Journal of Children's Rights 55; and Melissa CURLEY, "Combating Child Sex Tourism in South-East Asia: Law Enforcement Co-operation and Civil Society Partnership" (2OI4) 4I Journal of Law and Society 283.

7. UNODC, supra note 2 at $2 \mathrm{I}$.

8. Ibid., at 56,66, 67. See also UNODC, Patterns and Trends of Amphetamine-Type Stimulants and Other Drugs: Challenges for Asia and the Pacific (Vienna: UNODC, 20I3) at II, 79, 92; Koh-Lin CHIN and Roy GODSON, "Organized Crime and the Political-Criminal Nexus in China” (2006) 9 Trends in Organized Crime 5 .

9. They are Australia, Bangladesh, Bhutan, Brunei, the Cook Islands, Fiji, Hong Kong, India, Kiribati, Malaysia, the Marshall Islands, Myanmar, Nauru, New Zealand, Niue, Pakistan, Palau, Papua New Guinea, Samoa, Singapore, the Solomon Islands, Tokelau, Tonga, Tuvalu, and Vanuatu.

ıo. They include China, Cambodia, Japan, Indonesia, Macau, Mongolia, Timor-Leste, South Korea, Taiwan, Thailand, and Vietnam.

I I. States such as Brunei, Indonesia, and Pakistan are also influenced by the Islamic tradition, and local customary laws are regarded as important in the South Pacific, such as the Cook Islands, Fiji, Papua New Guinea, Samoa, and Tonga. See Esin ORUCU, "What is a Mixed Legal System: Exclusion or Expansion?" (2008) I 2 Electronic Journal of Comparative Law I; Jennifer C. CARE, "Cultures in Conflict: The Role of Common Law in the South Pacific" (2002) 6 Journal of South Pacific Law I.

I2. They include Nepal, the Philippines, and Sri Lanka. Orucu, supra note 11 at I6; L. Heckendorn URSCHELER, "Innovation in a Hybrid System: The Example of Nepal” (2012) I 5 Potchefstroom Electronic Law Journal, online: <http://www.saflii.org/za/journals/PER/>.

I3. I6 November 2000, 2225 U.N.T.S. 209 (entered into force 29 September 2003) [UNTOC]. 
co-operation. In the Asia-Pacific, approximately one half of states have ratified this instrument since its adoption. ${ }^{\mathrm{I}}{ }^{4}$ This might be compared with Europe, the Americas, the Middle East, or even Africa, where the vast majority of states have ratified it. ${ }^{15}$ There is therefore scope to encourage states in this region to accept and implement the relevant international standards stipulated in the UNTOC so that they can enhance their domestic, regional, and international efforts to tackle transnational organized crime.

The purpose of this paper is to explore some of the key benefits of international law pertinent to transnational organized crime in enhancing individual and collective actions, with particular reference to the UNTOC and human rights law. It looks at the harmonization of national criminal laws and procedures, the principle of mutual recognition of law enforcement decisions and measures, technical assistance, and protection of human rights, and analyzes how these are implemented by states in the Asia-Pacific. Relevant examples from other regions are also presented for comparison. The main conclusion is that the reluctance to abide by international law on transnational organized crime as well as human rights law is a serious issue in the Asia-Pacific compared to other regions of the world. However, the value of international law should not be dismissed, as an increasing number of states are implementing the relevant international standards with a view to promoting more effective actions.

\section{HARMONIZATION OF DOMESTIC CRIMINAL LAWS AND PROCEDURES}

International law on transnational organized crime as represented by the UNTOC and other instruments has been playing an important role in encouraging a degree of harmonization in domestic criminal laws and procedures among states in the Asia-Pacific. One way to do this is to promote common definitions to be used by the relevant law-enforcement authorities. If organized crime offences and their serious nature were understood consistently, this would naturally lead to smoother inter-state co-operation in investigation, prosecution, and punishment, thereby reducing safe havens for criminals. ${ }^{16}$ The UNTOC provides for a number of definitions in this regard. It should be noted from the outset that this instrument does not stipulate a definition of "organized crime" per se. Rather, it is to be understood as a "serious crime" committed by an "organized criminal group":

"Organized criminal group" shall mean a structured group of three or more persons, existing for a period of time and acting in concert with the aim of committing one or more serious crimes or offences established in accordance with this convention, in order to obtain, directly or indirectly, a financial or other material benefit. ${ }^{17}$

\footnotetext{
I4. Status of Ratification, online: United Nations Treaty Collection <https:/treaties.un.org/pages/viewdetails. aspx? src=ind\&mtdsg_no=xviii- $\mathrm{I} 2$ \& chapter= $=\mathrm{I}$ 8\&lang=en $>$.

I 5. Ibid.

16. Assistance in Harmonising National Legislation with the United Nations Convention against Organized Crime and Protocol Thereto: Discussion Paper by the Secretariat, Working Group on Technical Assistance, CTOC/COP/WG.2/2013/4, at para. 6.

17. Art. 2(a).
} 
A popular perception of organized crime among the general public perhaps is the involvement of large hierarchical criminal organizations like the Italian mafia, and this was particularly evident in the United States, where La Cosa Nostra has been in existence for some time. ${ }^{\mathrm{I} 8}$ This perception was strongly influenced by the so-called "alien conspiracy theory", which portrayed the Italian mafia as "a coherent and centralized international conspiracy of evil" which threatened the political, economic, and legal systems of the US. ${ }^{\text {I9 }}$ The term "organized crime" was coined in that country at the end of the nineteenth century, when the New York Society for the Prevention of Crime used the term to describe gambling and prostitution. ${ }^{20}$ At that time organized crime was understood as "illegal business deals involving politicians, police officers, lawyers or professional thieves", and not gangster- or mafia-type criminal groups. ${ }^{21}$ This changed in the I950s, when the term was used to describe the Italian mafia. In any event, the aforementioned definition of "organized criminal group" under the UNTOC does apply to this type of criminal organization. In the Asia-Pacific region, perhaps a good example is the Japanese yakuza. These criminal groups have hierarchical structures with the bosses (oyabun) at the top, assisted by lieutenants (wakagashira) in the middle and lower-ranking criminals at the bottom (kobun) of the pyramid. ${ }^{22}$

However, it was decided during the drafting stage of the UNTOC that the term should also apply to non-hierarchical groups. ${ }^{23}$ Article $2(\mathrm{c})$ in this regard states that a structured group does not need to have formally defined roles for its members, continuity of its membership, or a developed structure. This also seems to be in line with the ongoing scholarly debates since the I970s outside the US, ${ }^{24}$ which maintained that the perception of organized criminal groups being hierarchical was too simplistic and did not reflect the reality of contemporary organized crime. ${ }^{25}$ These scholars advocated a so-called "network model", in which organized crime was understood to be carried out by a collection or network of individuals, small groups, and departments, etc.

I 8. Donald CRESSEY, Theft of the Nation (New York: Harper and Row, I969); A.K. COHEN, "The Concepts of Criminal Organisation" (I977) I7 British Journal of Criminology 97; Cyrille FIJNAUT, "Organized Crime: A Comparison Between the United States of America and Western Europe" (I 990) 30 British Journal of Criminology $32 \mathrm{I}$; Letizia PAOLI and Cyrille FIJNAUT, eds., Organized Crime in Europe: Concepts, Patterns and Control Policies in the European Union and Beyond (Dordrecht: Springer, 2006).

I9. Michael WOODIWISS, "Transnational Organized Crime: The Global Reach of an American Concept" in Adam EDWARDS and Peter GILL, eds., Transnational Organized Crime: Perspectives on Global Security (London: Routledge, 2003), at I 5.

20. Michael WOODIWISS, "Transnational Organized Crime: The Strange Career of an American Concept" in Margaret BEARE, ed., Critical Reflections on Transnational Organized Crime, Money Laundering and Corruption (Toronto: University of Toronto Press, 2003), at 5.

2I. Paoli and Fijnaut, supra note I 8 at 24.

22. David KAPLAN and Alec DUBRO, Yakuza: Japan's Criminal Underworld (Berkeley: University of California Press, 2003) at I I 5-I6.

23. UNODC, Travaux Préparatoires of the Negotiation for the Elaboration of the United Nations Convention against Transnational Organized Crime the Protocols Thereto (New York: United Nations, 2006), 7-I 8 .

24. Jeffrey S. MCILLWAIN, “Organized Crime: A Social Network Approach" (I999) 32 Crime, Law and Social Change $30 \mathrm{I}$, at 303 .

25. Phil WILLIAMS and Roy GODSON, “Anticipating Organized and Transnational Crime” (2002) 37 Crime, Law and Social Change 3 I I at 332. 
collaborating with each other in varying combination. ${ }^{26}$ In looking at actual examples of organized criminal groups in the world, it is evident that many groups are indeed not hierarchical. Contrary to popular image, the Medellin and Cali cartels in Colombia consisted of "loose combinations of relatively small, family-based cocaine manufacturing firms that merely joined forces in the early I $9800^{2} .{ }^{27}$ It has also been argued that triads (Hong Kong) and "snakeheads" (China) operate largely through informal networks rather than formal structural organizations. ${ }^{28}$ It is therefore evident that the network model is equally important in understanding organized crime.

A few more points should be highlighted in relation to the above definition. According to Article 2(b), a "serious crime" means conduct constituting an offence punishable by a maximum deprivation of liberty of at least four years. The UNTOC also defines "criminal offences" as those which are committed for financial or material benefit. This is an important element, because what distinguishes organized crime from ordinary crime is the generation of longer-term, as opposed to immediate, profit or benefit. ${ }^{29}$ This means that criminal proceeds are normally diversified and reinvested in legal/illegal enterprises for the generation of sustained income for criminals. ${ }^{3 \circ}$ Many organized criminal groups are therefore comparable to legitimate corporations and businesses, except that they mainly operate in illegal markets.

An examination of state practice reveals that the definitions of an "organized criminal group" vary in the Asia-Pacific region. Under the Crimes Act I96I of New Zealand (as amended), for instance,

A group is an organized criminal group if it is a group of 3 or more people who have as their objective or one of their objectives (a) obtaining material benefits from the commission of offences that are punishable by imprisonment for a term of 4 years or more. ${ }^{3 \mathrm{I}}$

This definition is broadly in line with the UNTOC. Tonga and Tuvalu have also adopted similar definitions of a criminal group. ${ }^{32}$ In contrast, the Australian definition refers to a group consisting of two or more people for commission of offences carrying imprisonment of at least three years, without an element of material or financial

26. Gerben BRUINSMA and Wim BERNASCO, "Criminal Groups and Transnational Illegal Markets" (2004) 4I Crime, Law and Social Change 79 at 79.

27. Letizia PAOLI, "The Paradoxes of Organized Crime" (2002) 37 Crime, Law and Social Change 5I at 68.

28. Phil WILLIAMS, "Organising Transnational Crime: Networks, Markets and Hierarchy" in Phil WILLIAMS and Dimitri VLASSIS, eds., Combating Transnational Crime: Concepts, Activities and Responses (London: Frank Cass, 200I), at 77; Sheldon ZHANG and Koh-Lin CHIN, Characteristics of Chinese Human Smugglers: A Cross-National Study (Washington, DC: US Department of State, 2003); Yiu-Kong CHU, The Triads as Business (London: Routledge, 2008); Sheldon ZHANG and Koh-Lin CHIN, "Snakeheads, Mules and Protective Umbrellas: A Review of Current Research on Chinese Organized Crime" (2008) 50 Crime, Law and Social Change I77.

29. Tom OBOKATA, Transnational Organized Crime in International Law (Oxford: Hart Publishing, 2010) at 22.

30. Andreas SCHLOENHARDT, "Organized Crime and the Business of Migrant Trafficking: An Economic Analysis” (I999) 32 Crime, Law and Social Change 203; Cressey, supra note I 8 at 72.

3I. S. $98 \mathrm{~A}$.

32. Counter-Terrorism and Organized Crime Act 2013 and Counter-Terrorism and Transnational Organized Crime Act 2009, respectively. 
benefit. ${ }^{33}$ This makes the Australian definition much wider, as it can apply to a variety of ordinary crimes such as theft and criminal damage, if committed by two or more individuals. In addition, the Malaysian Penal Code I997 speaks of a group of two or more people, and a "serious crime" is defined as any offence punishable with imprisonment of ten years or more. ${ }^{34}$ Here, the threshold is higher than the definition of the UNTOC. Further, it is important to highlight that other states in the Asia-Pacific region have no definition of "organized crime" or "criminal group" incorporated into their domestic legislation. The main problem with these variations is that, if a crime is understood differently, this would make regional and international law enforcement co-operation more difficult, as states can refuse measures such as extradition or mutual legal assistance in criminal matters if conduct is not regarded as sufficiently serious, for instance. For those states without definitions, the principle of legality can also be affected, which in turn has ramifications for the human rights of the perpetrators of transnational organized crime. It is therefore helpful to have a common understanding across the region, and international law on transnational organized crime can fill this gap.

Another relevant aspect of harmonization is punishment. There are several advantages in this. When various forms of organized crime attract similar punishments, this can prevent forum shopping on the part of criminals (i.e. choosing jurisdictions where the punishment regimes are weak and concentrating their criminal activities there). This also reduces the situations where perpetrators receive different punishments for the same offences committed, and therefore enhances a sense of fairness on their part. Related to this, the harmonization of punishments can promote shared understanding of its proportionality for organized crime. ${ }^{35}$ This is important as varied understanding of proportionality can also hamper regional or international co-operation in criminal matters and cause more political tensions, as will be shown below on the discussion of the death penalty.

In reality, a great degree of discrepancy can be found among states in the Asia-Pacific once again. For instance, a minimum of three years' imprisonment is imposed for human trafficking in South Korea, ${ }^{36}$ and sexual offences against children carry between one and five years' imprisonment in Cambodia. ${ }^{37}$ Corruption by public

\footnotetext{
33. Criminal Code Act I995 as amended, s. 390.4 .

34. Act No. 574, s. I30U.

35. On the topic of proportionality in punishment, see Hugo A. BEDAU, "Retribution and the Theory of Punishment" (I978) 75 Journal of Philosophy 60I; Andrew VON HIRSCH, "Proportionality in the Philosophy of Punishment: From 'Why Punish?' to 'How Much?'”(I990) I Criminal Law Forum 259; Stephen T. PARR, "Symmetric Proportionality: A New Perspective on the Cruel and Unusual Punishment” (2000) 68 Tennessee Law Review 4I; Alice RISTROPH, "Proportionality as a Principle of Limited Government" (2005) 55 Duke Law Journal 263; Morris J. FISH, “An Eye for an Eye: Proportionality as a Moral Principle of Punishment" (2008) 28 Oxford Journal of Legal Studies 57; Ryan FLORIO, “The Capital Punishment Fits the Crime: A Comparative Analysis of the Death Penalty and Proportionality in the United States of America and the People's Republic of China" (2008) University of Miami International and Comparative Law Review 43; Dennis J. BAKER and Lucy ZAO, "Responsibility Links, Fair Labelling and Proportionality in China: Comparing China's Criminal Law Theory and Doctrine" (2009) UCLA Journal of International Law and Foreign Affairs 274.

36. Criminal Act 1953 as amended, art. 289.

37. Criminal Code 2009, arts. 34I, 342.
} 
officials (e.g. receiving bribes) is punishable with five years' imprisonment in Japan, ${ }^{38}$ while the same offence attracts imprisonment of ten years in Tonga. ${ }^{39}$ It is therefore apparent that the harmonization of national criminal laws and procedures as envisaged by international law on transnational organized crime has not been fully implemented by states in the Asia-Pacific.

These variations are understandable as the seriousness of crimes as reflected in national legislation depends on the cultural, social, political, and economic underpinnings of each state. This is more evident in the Asia-Pacific as substantive criminal laws and justice procedures vary among states, as shown above. Although it is extremely difficult to expect that all states across the region will harmonize their punishment regimes for all forms of organized crime, it is not impossible to find common ground by establishing a minimum threshold, for instance. In this regard, the notion of serious crime carrying a minimum of four years' imprisonment under the UNTOC can serve as a good starting point. The fact that this provision was included in the final text demonstrates that participating states in the negotiation of this instrument, including those in the Asia-Pacific, were willing to come to a consensus. It is therefore premature to dismiss the value of international law on transnational organized crime altogether.

The situation in this region may be contrasted with Europe, in particular the European Union (EU) and its Member States. Harmonization (or approximation within the EU legal order) of national criminal laws and procedures has long been recognized as a useful tool to combat serious crimes with a cross-border dimension, including organized crime. ${ }^{40}$ This principle has been reaffirmed most recently in the Treaty on the Functioning of the European Union (TFEU), ${ }^{4 \mathrm{I}}$ which has restructured the EU legal order, including the Area of Freedom, Security and Justice. A recent attempt to facilitate harmonization in the area of organized crime is the adoption of the EU Directive on Preventing and Combating Trafficking in Human Beings and Protecting Its Victims. ${ }^{42}$ It provides for, among others, a common definition of human trafficking to be adopted by Member States, which mirrors the one given by the Protocol to Prevent, Suppress and Punish Trafficking in Persons, Especially Women and Children, attached to the UNTOC. ${ }^{43}$ This is a legally binding instrument, and the TFEU allows for infringement proceedings to be instituted against Member States that have failed to implement it. ${ }^{44}$ The enforcement mechanism in the case of

38. Penal Code 1907 (Act No. 45) as amended, art. I97.

39. Counter-Terrorism and Transnational Organized Crime Act 2013, s. 67.

40. On the topic of harmonization in the EU legal order, see Kai AMBOS, "Is the Development of a Common Substantive Criminal Law for Europe Possible?" (2005) I 2 Maastricht Journal of European and Comparative Law I73; Anne WEYEMBERGH, “The Functions of Approximation of Penal Legislation within the European Union" (2005) I2 Maastricht Journal of European and Comparative Law I49; Anne WEYEMBERGH, "Approximation of Criminal Laws, the Constitutional Treaty and the Hague Programme" (2005) 42 Common Market Law Review I567; Tom OBOKATA, "Key EU Principles to Combat Transnational Organized Crime" (20II) 48 Common Market Law Review 80I; Francesco CALDERONI, Organized Crime Legislation in the European Union (Heidelberg: Springer, 2010).

4I. [2OI2] OJ C 326/47 (entered into force I December 2009) arts. 82, 83.

42. [2OII] OJ L IOI/I.

43. I 5 November 2000, 2237 U.N.T.S. 3 I9 (entered into force 25 December 2003 ).

44. Art. 258. 
non-implementation is therefore stronger within the EU. As of October 20I4, twenty-five Member States (out of twenty-eight) are said to have transposed this Directive into their domestic legislation. ${ }^{45}$ Despite the fact that criminal laws and justice processes also vary among the EU Member States (e.g. common-law and civil-law traditions), they seem to have been more willing to recognize the value of harmonization of national criminal laws and procedures in combating transnational organized crime. ${ }^{46}$ There is of course no guarantee that the EU practice would work in the Asia-Pacific or indeed in other regions, given that political, legal, social, and economic developments are different across the globe. It is also important to recognize that the implementation of EU measures is not always executed in a timely and effective manner. ${ }^{47}$ However, all states, regardless of where they are located, certainly have a common goal of effectively preventing and suppressing transnational organized crime, and sharing good practices and difficulties is a constructive way to develop an evidence-based strategy to tackle this crime. Therefore, states in the Asia-Pacific may be able to benefit from the European experience.

As succinctly put by one of the Working Groups of the Conference of Parties to the UNTOC, harmonization is not a one-time thing. Rather it is an ongoing process which all State Parties should respect and implement to strengthen their action against organized crime. ${ }^{48}$ It is encouraging to see in this regard that the principle of harmonization is gradually being achieved in some areas. The prosecution and punishment of human trafficking is a case in point. The definitions of human trafficking adopted in the domestic legislation of Bhutan, ${ }^{49}$ India, ${ }^{50}$ Malaysia, ${ }^{51}$ Myanmar, ${ }^{52}$ the Philippines, ${ }^{53}$ Singapore, ${ }^{54}$ and Thailand ${ }^{55}$ are broadly in line with that of the Protocol on Human Trafficking noted above, and this is a good example of international law on transnational organized crime making a positive contribution. If they have not done so, states in the Asia-Pacific could also consider adopting a definition of an organized criminal group in line with the UNTOC. In addition to encouraging better inter-state co-ordination in the investigation, prosecution, and punishment of organized crime, this would also enhance the principle of legality, particularly the maxim nullum crimen, nulla poena sine praevia lege poenali (no crime and no punishment without a

45. Mid-Term Report on the Implementation of the EU Strategy Towards the Eradication of Trafficking in Human Beings, European Commission, COM (2014) 635 final.

46. It is worth noting here that the European Union is the only regional organization which signed the UNTOC.

47. See, for instance, the European Commission's Report, supra note 45, which talks about infringement actions brought against some states for non-implementation; and Report from the Commission to the Council and the European Parliament Based on Article Io of the Council Framework Decision of I9 July 2002 on Combating Trafficking in Human Beings, European Commission, COM (2006) I 87 final.

48. Working Group on Technical Assistance, supra note I 6 at para. I I.

49. Penal Code 2004 as amended in $201 \mathrm{I}$, s. I 54.

50. Penal Code as amended in 2013, s. 370.

5. Anti-Trafficking in Persons Act 2007.

52. Anti-Trafficking in Persons Law 2005.

53. Expanded Anti-Trafficking in Persons Act 2012.

54. Prevention of Human Trafficking Act 2014.

55. Anti-Trafficking in Persons Act 2008. 
pre-existing penal law). This in turn can boost public confidence in law enforcement at the national level.

\section{THE PRINCIPLE OF MUTUAL RECOGNITION}

Another important role of international law on transnational organized crime is the promotion of the principle of mutual recognition among states in the Asia-Pacific. Simply put, it means that decisions made by law-enforcement or judicial authorities in one state are to be recognized and implemented in another and, once again, this is a relatively well-established concept within the EU legal order. ${ }^{56}$ Mutual recognition is useful as it is not contingent upon the harmonization of national criminal laws and procedures, although the latter certainly can facilitate the former. Rather, it operates despite the differences in national criminal laws and procedures. Put succinctly, then, harmonization aims to eliminate the differences while mutual recognition is about respecting them. This perhaps is a preferred option for states generally as there is less need to modify their national criminal laws and procedures in order to accommodate others, thereby preserving their sovereignty. If states in the Asia-Pacific region can develop a high level of mutual recognition, this would make inter-state law enforcement co-operation much easier and quicker.

Although the term "mutual recognition" is not evident, the UNTOC indeed recognizes this implicitly in its text. One example is the offences relating to organized criminal groups under Article 5. The rationale for including this provision is to prosecute and punish those who contribute to the operations of organized crime groups without directly committing substantive offences. ${ }^{57}$ This can be used to target mafia bosses who simply order their subordinates to commit various crimes, for instance. Article 5 provides for two options for states to take: (i) agreeing to commit serious crimes; and (ii) participating in the activities of organized criminal groups. The first type is also known as "conspiracy" to commit a crime and is accepted by common-law jurisdictions, whereas the second one is generally recognized in civil-law jurisdictions. ${ }^{58}$ In the Asia-Pacific region, Australia, ${ }^{59} \mathrm{New}$ Zealand, ${ }^{60}$ Singapore, ${ }^{61}$ and Papua New Guinea ${ }^{62}$ recognize the offence of conspiracy, while the domestic legislation of China, ${ }^{63}$ Samoa, ${ }^{64}$ Taiwan, ${ }^{65}$ Tonga, $^{66}$ and Tuvalu $^{67}$ is

\footnotetext{
56. Obokata, supra note 40.

57. UNODC, Legislative Guides for the Implementation of the United Nations Convention against Transnational Organized Crime and Protocols Thereto (Vienna: UNODC, 2004) at $2 \mathrm{I}$.

58. Andreas SCHLOENHARDT, "Fighting Organized Crime in the Asia-Pacific Region: New Weapons, Lost Wards”, Asian Law Institute, Working Paper Series No. 22, 2001 at 3-5.

59. Criminal Code Act 1995 as amended, s. II.5(I).

60. Crimes Act I96I as amended, s. 3 IO.

61. Penal Code 2008 (Revised Edition), s. I20A.

62. Criminal Code 1974 as amended, ss. 5I 5-I7.

63. Criminal Law of the People's Republic of China I979 as amended, art. 294.

64. Crimes Act 2013, s. I46.

65. Criminal Code 1954 as amended, s. I 54.

66. Counter-Terrorism and Organized Crime Act 2013, s. 66.

67. Counter-Terrorism and Transnational Organized Crime Act 2009, s. 66.
} 
based on the participation model. ${ }^{68}$ Therefore the UNTOC is flexible as it allows states to establish relevant offences in accordance with their domestic legal systems, instead of strictly facilitating harmonization. The expectation here, then, would be that states will respect each other's legislation and facilitate co-operation despite this difference. Having said this, it has been argued cogently that the divergence can be a double-edged sword as it leaves too much discretion to states. ${ }^{69}$

The mutual recognition principle is more relevant to law enforcement co-operation. Extradition is a case in point. It is a process of handing over a suspect/criminal from one jurisdiction to another for the purposes of prosecution and punishment. This is conducted mainly through bilateral and/or multilateral treaties, as well as reciprocity or comity. ${ }^{70}$ Another example is mutual legal assistance in criminal matters. This facilitates, among other things, the gathering and exchange of intelligence/evidence and the execution of orders (such as the search, seizure, and confiscation of criminal proceeds) received from requesting states. ${ }^{7 \mathrm{I}}$ Its scope is therefore wider than extradition. Other relevant measures include international co-operation in confiscation, ${ }^{72}$ joint investigations, ${ }^{73}$ the transfer of criminal proceedings, ${ }^{74}$ and general law-enforcement co-operation. ${ }^{75}$ The UNTOC provides detailed guidance on these measures.

Traditionally, requests for law enforcement co-operation have been transmitted through diplomatic channels and/or letters rogatory, which were more time-consuming and often led to delays in executing these requests. ${ }^{76}$ This has further been complicated by the divergence in domestic criminal laws and justice procedures. The UNTOC contains a number of provisions, which are designed to mitigate these and encourage states to facilitate smoother and faster co-operation. Article I6(3), for instance, provides that offences covered in the UNTOC are to be deemed extraditable, thereby reducing the possibility of states designating certain offences political in nature and preventing co-operation. Article 16(8) also provides for expediting extradition procedures and simplifying evidentiary requirements. In addition, Article 27 encourages direct co-operation between law-enforcement agencies instead of going through diplomatic channels. These measures, in effect, are designed to encourage mutual trust and recognition among states. It is worth highlighting in this regard that, some states in the Asia-Pacific, particularly among the Pacific

68. For further discussions, see Criminalization of Participation in an Organized Criminal Group: Background Paper by the Secretariat, Working Group on Technical Assistance, CTOC/COP/WG.2/20I4/2.

69. Andreas SCHLOENHARDT, Palermo in the Pacific: Organized Crime Offences in the Asia Pacific Region (Boston: Martinus Nijhoff Punishers, 2010) at 402.

70. Information Submitted by States in Their Responses to the Checklist/Questionnaire on the Implementation of the United Nations Convention Against Transnational Organized Crime for the First Reporting Cycle, CTOC/COP/2008/CRP.7.

7I. UNTOC, art. I8.

72. Art. I3.

73. Art. I9.

74. Art. 2I.

75. Art. 27.

76. Obokata, supra note 29 at 64 . 
Islands, use a system of endorsement of extradition warrants which reduces the amount of time to execute. ${ }^{77}$

At the time of ratification or accession, states can opt to use the UNTOC as a framework to facilitate inter-state law-enforcement co-operation in the absence of the pre-existing treaties. In relation to extradition, this is particularly important in the Asia-Pacific region as there is currently no comprehensive regional treaty on the subject, unlike Europe, Africa, or the Americas. ${ }^{78}$ There are two subregional treaties on mutual legal assistance: the South Asian Association for Regional Cooperation (SAARC) Convention on Mutual Legal Assistance in Criminal Matters, ${ }^{79}$ and the Association of Southeast Asian Nations (ASEAN) Treaty on Mutual Legal Assistance in Criminal Matters. ${ }^{80}$ Nevertheless, these instruments are inevitably limited to the Member States of the SAARC and ASEAN. In order to facilitate more effective co-operation within and outside the Asia-Pacific, therefore, the UNTOC can play a more prominent role.

In practice, not many states in the region are using the UNTOC as a framework. At the time of the first reporting cycle in 2008 , of fifty-nine states which declared to use this instrument as a legal basis for extradition, only three of them were from the Asia-Pacific. ${ }^{8 \mathrm{I}}$ Similarly, in relation to mutual legal assistance, out of eighty states which said they would use Article $\mathrm{I} 8$ as a legal basis, nine were from the region. ${ }^{82}$ These facts indicate that there has not been enough inclination to rely on international law on transnational organized crime to facilitate law enforcement co-operation. Indeed, it has been reported that the number of bilateral agreements is higher in Asia compared to Africa or the Americas. ${ }^{83}$

While it is important to acknowledge the importance and usefulness of these bilateral agreements, the UNTOC is still beneficial for many reasons. Bilateral agreements may reflect political, economic, and other issues of bilateral concern, often leading to the adoption of different languages and provisions depending on the states in question. This can result in a fragmented, rather than integrated, approach to combating transnational organized crime as different measures might be taken. To illustrate this with some examples, while a refusal to extradite its own nationals to Mongolia is mandatory for South Korea, it is discretionary with others, including India and Vietnam. ${ }^{84}$ In a similar vein, Australia exercises criminal jurisdiction over (i.e. prosecute) its nationals if it refuses extradition to Hong Kong, Indonesia, and the Philippines, but it will do so only upon request

77. Asian Development Bank (ABD) and Organization for Economic Co-operation and Development (OECD), Mutual Legal Assistance, Extradition and Recovery of Proceeds of Corruption in Asia and the Pacific (Mandaluyong City/Paris: ADB/OECD, 2007) at 73.

78. Bilateral and Multilateral Co-operation Arrangements and the Co-ordinating Functions of the Central Authorities, Working Group on International Cooperation, CTOC/COP/WG.3/20I4/2 at para. I9.

79. 3 August 2008, online: SAARC: <http://saarc-sec.org/SAARC-Conventions/63/>.

80. 29 November 2004 , online: ASEAN <http://agreement.asean.org/home/index/2.html>.

8I. They were Cambodia, China, and the Philippines. Information Submitted by States, supra note 70.

82. Ibid. They were Australia, Cambodia, China, Indonesia, Malaysia, Myanmar, New Zealand, the Philippines, and Thailand.

83. Working Group on International Cooperation, supra note 78 at paras. I4, I 5 .

84. $\mathrm{ADB}$ and OECD, supra note 77 at 39. 
by others such as Malaysia. ${ }^{85}$ All of these may lead to undesirable consequences such as impunity, different treatments for perpetrators, and an increased possibility of forum shopping. These issues can be mitigated if states use a single instrument like the UNTOC with the same rules applicable to all Parties. Further, this treaty is more useful in bridging diverse legal traditions as it can nurture common understanding (harmonization) and mutual trust (mutual recognition) and saves time for states, particularly those without pre-existing bilateral agreements, as there would be less need to draft numerous agreements. Therefore, the value of international law on organized crime should not be underestimated once again.

\section{TECHNICAL ASSISTANCE}

In addition, international law on transnational organized crime is beneficial as it provides a framework to facilitate technical assistance. This is particularly important in the Asia-Pacific as the majority are developing states which may not have sufficient resources, expertise, and capacity to combat transnational organized crime more effectively. ${ }^{86}$ Article 29 of the UNTOC places a clear obligation on states to assist each other in the areas of research, operational training, and information exchange, as well as extradition and mutual legal assistance. Article 30 also obliges them to provide financial and other assistance to developing states for capacity building. This makes it clear that wealthy developed states in the Asia-Pacific and elsewhere have the responsibility to assist others. Indeed, this does happen in practice. In 20I2, for instance, the government of Japan provided financial and technical assistance to states including Myanmar and the Philippines so that they could enhance their capability to address crimes such as drug and human trafficking. ${ }^{87}$ The US government has also implemented technical assistance on cross-border financial investigation in Bangladesh, the Maldives, Nepal, Pakistan, and the Philippines. ${ }^{88}$ More of these efforts should be encouraged in the region.

In addition, as envisaged by Article 30 of the UNTOC, the role of international organizations in providing technical assistance should be emphasized. The most important one is United Nations Office on Drugs and Crime (UNODC), which provides a variety of assistance measures globally, including in the Asia-Pacific region. In 201 2, for instance, the UNODC Regional Office for Southeast Asia and the Pacific hosted legislative drafting workshops on international co-operation in the Philippines and Laos, and this led to the actual enactment of legislation on extradition and mutual legal assistance in these states. ${ }^{89}$ It has also provided legislative assistance relating to

85. Ibid., 38 .

86. Roderic BROADHURST and Nicholas FARRELLY, "Organized Crime Control in Asia: Experiences from India, China, and the Golden Triangle" in Letizia PAOLI, ed., The Oxford Handbook of Organized Crime (Oxford: Oxford University Press, 2014), at 649.

87. Ministry of Foreign Affairs, Japan's Official Development Assistance White Paper 2013 (Tokyo: Ministry of Foreign Affairs, 20I3) at $9 \mathrm{I}$.

88. US Department of State, International Narcotics Control Strategy Report: Volume II-Money Laundering and Financial Crimes (Washington, DC: US Department of State, 201 5 ) at 6.

89. Working Group on Technical Assistance, supra note I6 at para. 29. 
trafficking and the smuggling of human beings to forty-five Member States of the Bali Process, ${ }^{90}$ the majority of which are from the Asia-Pacific region..$^{9 \mathrm{I}}$ In addition, the UNODC in 20I 4 worked with states in the Asia-Pacific to establish the Asset-Recovery Inter-Agency Network. ${ }^{92}$

Although it is important to recognize these and other initiatives being undertaken in the Asia-Pacific region by the UNODC, what should be encouraged is more proactive involvement of regional organizations such as ASEAN and the SAARC. Having effective regional mechanisms/arrangements can enhance solidarity and mutual trust among states in the Asia-Pacific. While ASEAN has adopted the Declaration on the Prevention and Control of Transnational Crime ${ }^{93}$ in 1997 and the Plan of Action to Combat Transnational Crime ${ }^{94}$ in 1999, the bulk of its activities seem to be concentrated on having practitioner/ministerial meetings without implementing more practical measures for inter-state co-operation and capacity building. The same conclusion can be reached in relation to the SAARC. A good starting point perhaps is the establishment of the Center to Combat Transnational Crime by ASEAN, which was envisaged in the Plan of Action but has not materialized as of this writing.

A lack of financial resources within the Asia-Pacific is a major problem, but this should not be an excuse not to assist each other, as there are ways to mitigate this. Effective legislative frameworks and procedures for confiscation of criminal proceeds are crucial in this regard. As noted above, the annual profits made from organized crime in the region amount to $\$ 90$ billion approximately, and this pot of money can and should be returned to the states in the Asia-Pacific to enable them to strengthen domestic and regional capacities to tackle organized crime. This can also send a strong message to criminals that they cannot benefit from their criminal activities. The first international instrument touching upon this is the Convention Against Illicit Traffic in Narcotics and Psychotropic Substances, ${ }^{95}$ but the UNTOC applies to organized crime generally, and therefore provides a better framework. Under Article I 2, states have to enhance their domestic efforts to confiscate criminal proceeds, while Article I 3 places an additional obligation to facilitate international co-operation for this purpose. Finally, sharing the confiscated proceeds with other states as well as international organizations is envisaged under Article I4.

In terms of steps to be taken, in addition to criminalizing money laundering and authorizing the relevant bodies, including the judiciary, to initiate the confiscation of criminal proceeds, states in the Asia-Pacific must sufficiently address issues such as bank secrecy, tax avoidance, obstruction of justice, and corruption, all of which

\footnotetext{
90. Online: <http://www.baliprocess.net/>.

91. Provision of Technical Assistance to States in the Implementation of the United Nations Convention Against Transnational Organized Crime and the Protocols Thereto: Report of the Secretariat, CTOC/ $\mathrm{COP} / 20{ }_{4} / \mathrm{I}$ I at para. Io.

92. Activities of the United Nations Office on Drugs and Crime to Promote the Implementation of the Provisions on International Cooperation in the United Nations Convention Against Transnational Organized Crime: Report of the Secretariat, CTOC/COP/20 I $4 / 10$ at para. 34.

93. 20 December 1997. The ASEAN Secretariat, ASEAN Documents on Combating Transnational Crime and Terrorism (Jakarta: ASEAN, 2007) at 9.

94. 23 June 1999 , ibid., at 23.

95. 20 December I988, I 582 U.N.T.S. 95 (entered into force I I November I990), art. 5.
} 
contribute to the generation of criminal proceeds. They should also establish a specialized agency staffed with sufficiently trained law-enforcement officials. In addition, financial investigations should be conducted in parallel with criminal investigations into organized crime, so that the relevant authorities can identify and trace criminal proceeds sooner rather than later. Further, more proactive co-operation and communications with private financial and related institutions, which are likely to be in contact with criminal proceeds, must be facilitated. Regionally, the establishment of the Asset Recovery Inter-Agency Network noted above is a positive step forward, but more practical training and intelligence sharing should accompany this. Once again, the willingness of states in the Asia-Pacific to observe and implement harmonization and mutual recognition is important in order to enhance their capacity to identify and confiscate criminal proceeds.

\section{THE PROTECTION OF HUMAN RIGHTS}

Finally, international law is also important in protecting the human rights of both victims and perpetrators of organized crime. In relation to victims, some forms of organized crime such as human trafficking, sexual and labour exploitation, as well as child sex tourism clearly violate their human rights, and victim protection must constitute an integral part of action against these crimes. From a practical point of view, sufficient protection will naturally encourage victims to trust the authorities and become more willing to co-operate with them in criminal investigations and proceedings against perpetrators. Unfortunately, international law on transnational organized crime is weak in this regard. It is important to acknowledge that Article 25 of the UNTOC does touch upon victim protection and assistance. It obliges states to provide appropriate measures, including compensation, and to reflect victims' views during criminal proceedings. Nevertheless, its language is not strong, as can be seen from the phrases such as "within its means" and "subject to its domestic law", leaving open the possibility of states not providing sufficient protection. While the Protocol on Human Trafficking attached to the UNTOC provides for protection of privacy, assistance during criminal proceedings, protection of the physical and mental wellbeing of victims, and temporary/permanent residence permits for trafficked victims, ${ }^{96}$ the relevant provisions suffer from the same problem as Article 25, and the instrument's scope is inevitably limited to victims of human trafficking.

This means that international law on transnational organized crime must be supplemented by international human rights law. The benefit of using this branch of international law is that it covers all victims of organized crime with a human rights dimension. The International Covenant on Civil and Political Rights97 (ICCPR), for instance, obliges states to "ensure that any person whose rights or freedoms as herein recognized are violated shall have an effective remedy, notwithstanding that the violation has been committed by persons acting in an official capacity". ${ }^{8}$ In relation to human trafficking, the United Nations Human Rights Council explicitly acknowledged

\footnotetext{
96. Arts. 6, 7 .

97. I6 December I966, 999 U.N.T.S. I7I (entered into force 23 March I976) [ICCPR].

98. Art. 2.
} 
that this provision applied to the victims of this crime, ${ }^{99}$ and it seems reasonable to assume that the same is true for other forms of organized crime with a human rights dimension. For those states which have not ratified the ICCPR, there are other human rights treaties, such as the ILO Forced Labour Convention, ${ }^{100}$ the Convention on the Elimination of All Forms of Discrimination Against Women, ${ }^{\text {IOI }}$ the Convention on the Rights of the Child, ${ }^{\mathrm{IO}}$ and its Protocol on Sale of Children, Child Prostitution, and Child Pornography, ${ }^{\mathrm{IO} 3}$ which place relevant obligations to protect the affected victims.

A wide variety of measures should be taken to protect the victims of organized crime. First and foremost, their life and physical/mental wellbeing must be protected and restored. It has been well established that state responsibility remains even when these violations of human rights have been committed by non-state actors, ${ }^{\text {I04 }}$ and this should apply to perpetrators of organized crime. If these victims are to participate in criminal investigations and proceedings, then their identity and safety must be guaranteed through, among other things, effective witness protection schemes, coupled with other relevant assistance including interpretation/translation, legal assistance, safe accommodation, as well as temporary residence permits in cases where these victims are foreign nationals. Moreover, access to compensation must be guaranteed to victims of crime. These are some of the measures which are established under international human rights law. ${ }^{\text {I05 }}$

A similar picture emerges in relation to the human rights of perpetrators of organized crime. The UNTOC does not contain extensive provisions on the rights of defendants and therefore must be supplemented by international human rights law. In addition to widely debated and scrutinized human rights such as the right to liberty and security, and prohibition against torture, inhuman, or degrading treatment, ${ }^{106}$ an important issue in the context of law enforcement against transnational organized crime is the use of special investigative techniques such as controlled delivery, surveillance, interception of communications, and undercover operations, and their impact on one's right to privacy. While Article 20 of the UNTOC encourages states to use these measures in order to promote intelligence-led law enforcement, it does not mention any relevant human rights norms and principles at all, and this raises a great degree of concern. This shortcoming is mitigated by international human rights law. For instance, the UN Human Rights Committee, which monitors the implementation of the ICCPR, has stated that in order to justify interferences with the right to privacy, states must specify in detail the circumstances under which such

99. Resolution 20/r: Trafficking in Persons, Especially Women and Children: Access to Effective Remedies for Trafficked Persons and Their Right to an Effective Remedy for Human Rights Violations, A/HRC/20/ LI (2OI2).

I00. 28 June 1930, 39 U.N.T.S. 55 (entered into force I May 1932).

I0I. I8 December 1979, I 249 U.N.T.S. 3 (entered into force 3 September 198I).

I02. 20 November 1989, I 577 U.N.T.S. 3 (entered into force 2 September 1990).

I03. 25 May 2000, 217I U.N.T.S. 227 (entered into force I 8 January 2002).

I04. See, for instance, the landmark case of Velasquez Rodriquz v. Honduras, Inter-Am.Ct.H.R. (Ser. C) No. 4 (I988).

I05. See Tom OBOKATA, Trafficking of Human Beings from a Human Rights Perspective: Towards a Holistic Approach (Leiden: Martinus Nijhoff Publishers, 2006).

Io6. The ICCPR, arts. 7, 9, ro. 
interferences may be permitted in their national legislation. ${ }^{107}$ In other words, these measures should have a clear legal basis. In addition, it has been established that any interference must be necessary and reasonable, in that it must be proportionate to the legitimate aim pursued. ${ }^{108}$ While acknowledging that crime prevention is a legitimate aim, the UN High Commissioner for Human Rights has also endorsed points raised by the Human Rights Committee. ${ }^{\text {I09 }}$ More recently, in March 2015, in recognizing the need to discuss and examine the right to privacy in the contexts, among others, of surveillance and its lawfulness, the UN Human Rights Council established the Special Rapporteur on the Right to Privacy. ${ }^{\text {Io }}$ Another important issue is one's right to a fair trial. It has been recognized, for instance, that undercover operations could amount to entrapment if a crime was instigated by the law-enforcement agencies, and that this would undermine the right to a fair trial. ${ }^{\text {II }}$ The use of improperly obtained evidence in court also raises an issue with respect to this, particularly when it is the sole evidence relied upon and/or the accused did not have an opportunity to challenge its authenticity. ${ }^{\text {I } 2}$

In looking at state practice in the Asia-Pacific, discrepancies are once again evident. While China, ${ }^{\text {II3 }}$ Hong Kong, ${ }^{\text {II } 4}$ Japan, ${ }^{\text {II } 5}$ Myanmar, ${ }^{\text {II } 6}$ New Zealand, ${ }^{\text {II } 7}$ Papua New Guinea, ${ }^{\text {I } 8}$ South Korea, ${ }^{\text {II }}$ Taiwan, ${ }^{\text {I20 }}$ Thailand, ${ }^{\text {I2I }}$ and Tonga ${ }^{\text {I22 }}$ enacted legislation on special investigative techniques, many of these laws are not comprehensive enough in that they do not cover all forms of these measures. In the Cook Islands and Fiji, the relevant measures are limited to certain crimes such as participation in criminal organization or drug trafficking, ${ }^{\mathrm{I} 3}$ and there is no clear legal basis at all in Bangladesh, Sri Lanka, and Vietnam. ${ }^{\text {I24 }}$ These examples go against the aforementioned human rights norms. This may be compared with the UK's Regulation

I07. General Comment No. I6 (Right to Privacy) (I988), HRI/GEN/I/Rev.I at para. 8.

I08. See, for instance, Toonen v. Australia, Communication No. 488/I992, CCPR/C/WG/44/D/488/I992 at para. 8.3; General Comment No. 3 I (The Nature of the General Legal Obligation) (2004), CCPR/C/2I/ Rev.I/Add.I3 at para. 6.

109. The Right to Privacy in the Digital Age, A/HRC/27/37 (2014).

I IO. Resolution 28: Human Rights, Democracy and the Rule of Law, A/HRC/28/L.24 (20I 5 ).

I I I. See, for instance, Teixeira de Castro v. Portugal (I998), Application No. 25829/94; Ludi v. Switzerland (I992), Application No. I2433/86; Khudobin v. Russia (2006), Application No. 59696/oo.

I I2. Schenk v. Switzerland (I988), Application No. I0862/84; Khan v. United Kingdom (2000), Application No. $35394 / 97$.

I 13. Criminal Procedural Law I979 as amended in 201 2, art. I48.

I 4. Interception of Communications and Surveillance Ordinance 2006.

I I 5. Communications Interception Law I999.

I 16. Privacy International, Right to Privacy in Myanmar (London: Privacy International, 201 5) at 5-6.

I I7. Search and Surveillance Act 2012.

I 18. Protection of Private Communications Act 1973.

I 19. Protection of Communications Secrets Act 2002.

I 20. Communications Protection and Surveillance Act I999 as amended.

I2I. Telegraph and Telephone Act 1934.

I22. Police Act 2010.

I23. ABD and OSCE, The Criminalisation of Corruption in Asia and the Pacific (Mandaluyong City/Paris: $\mathrm{ADB} / \mathrm{OECD}, 2008)$ at $\mathrm{I} 66$ and $\mathrm{I} 85$.

I24. Ibid., at 107, 474-5, 5 I 5 . 
of Investigation Powers Act 2000 (as amended), which governs surveillance, interception of communications, covert human intelligence sources, as well as the use of CCTV. This undoubtedly is a better model in terms of legality and clarity. In relation to entrapment, Australia, ${ }^{\mathrm{I} 25}$ India, ${ }^{\mathrm{I} 26}$ and Singapore ${ }^{\mathrm{I27}}$ do not recognize the defence of entrapment in criminal proceedings, in line with the common-law tradition that the manner in which evidence was obtained is not relevant. ${ }^{\mathrm{I} 28}$ However, judges have discretion not to admit evidence obtained by entrapment in some jurisdictions. ${ }^{\mathrm{I}} 9$ In contrast, the reduction of sentences is implemented in China instead of excluding evidence obtained as a result of entrapment. ${ }^{\mathrm{I}}{ }^{\circ}$ In summary, all of these highlight the need to promote the relevant human rights principles more widely.

In addition, asset recovery or the confiscation of criminal proceeds entails some human rights issues. The first question which should be asked is whether criminals can retain the proceeds of organized crime under the rubric of "right to property", which is recognized by the Universal Declaration of Human Rights. ${ }^{\text {I3 }}$ While this right is not stipulated in the legally binding universal instruments such as the ICCPR or the International Covenant on Economic, Social and Cultural Rights, ${ }^{132}$ it is recognized regionally in Africa, ${ }^{\mathrm{I} 33}$ the Americas, ${ }^{\mathrm{I} 4}$ and Europe. ${ }^{\mathrm{I} 35}$ A lack of clear guidance and jurisprudence in the Asia-Pacific region prompts an examination of other regions, and it becomes evident that one does not have the right to property obtained as a result of criminal activities. This right is regarded as a "qualified right", in that in can be restricted in the public interest or as prescribed by law. ${ }^{136}$ What is evident, then, is that criminal proceeds are not generally protected by human rights law. It is also worth pointing out that the temporary seizure of property, including vehicles and aircraft used for criminal activities, is not regarded as deprivation of such property. ${ }^{137}$ However, as with the right to privacy, confiscation must be proportionate to the

\footnotetext{
I25. Ridgeway (1995) I 84 CLR I9.

I26. R.K. Anand v. Registrar of the Delhi High Court (2009) 8 SCC 106.

I27. Law Society of Singapore v. Tan Guat Neo Phyllis [2008] 2 SLR 239; Mohamed Emran bin Mohamed Ali v. Public Prosecutor [2008] 4 SLR 4II.

I28. John D. JACKSON and Sarah J. SUMMERS, The Internationalisation of Criminal Evidence: Beyond the Common Law and Civil Law Traditions (Cambridge: Cambridge University Press, 201 2) at I 53.

I29. This is the case for Australia and India.

I30. The Supreme Court Document 324 (2008).

I3 I. Io December I948, G.A. Res. 2 I7 A (III), art. I7.

I32. I6 December I966, 993 U.N.T.S. 3 (entered into force 3 January 1976).

I33. African Charter on Human and Peoples' Rights, 27 June I98 I, I 520 U.N.T.S. 2 I7 (entered into force 2 I October I986), art. I4.

I34. American Convention on Human Rights, 22 November I969, II44 U.N.T.S. I43 (entered into force I 8 July I978), art. 2 I.

135. Protocol I to the European Convention on Human Rights, 20 March I952, E.T.S. No. 9 (entered into force I 8 May I954), art. I.

I36. Art. I of the Protocol I to the ECHR states: "No one shall be deprived of his possessions except in the public interest and subject to the conditions provided for by law and by the general principles of international law; 2) The preceding provisions shall not, however, in any way impair the right of a State to enforce such laws as it deems necessary to control the use of property in accordance with the general interest or to secure the payment of taxes or other contributions or penalties." Similar language can be found in art. $2 \mathrm{I}$ of the ACHR and art. I4 of the African Charter.
}

137. Air Canada v. United Kingdom (1995), Application No I 8465/9I. 
legitimate aim pursued. ${ }^{\mathrm{I}}{ }^{8}$ This means that some of the principles noted above, such as the existence of a legal basis and its clarity, are pertinent. ${ }^{\text {I39 }}$

The confiscation regimes can be divided roughly into two categories. The first is conviction-based confiscation, which is widely utilized by states. As the name suggests, a confiscation order is issued by the competent authorities, normally the judiciary, after a perpetrator is convicted of organized crime. In this sense, this type of confiscation can be seen as an additional form of punishment. In addition, some states, particularly common-law jurisdictions including Canada, Ireland, the UK, and the US, ${ }^{\text {I }}{ }^{\circ}$ also rely on so-called non-conviction-based confiscation through civil proceedings. This can be facilitated without a perpetrator being convicted, if the domestic court determines, on the balance of probabilities, that the proceeds in question have derived from criminal activities. Here, the guilt is associated with property and not the offenders. The UNTOC does not directly refer to convictionor non-conviction-based confiscation in its text. However, it recognizes that confiscation is to be implemented in accordance with the domestic law of each State Party, ${ }^{\text {I I }}$ thereby respecting the diversity in confiscation mechanisms. In the Asia-Pacific region, Australia, ${ }^{\mathrm{I} 42}$ Brunei, ${ }^{\mathrm{I}}{ }^{3}$ New Zealand, ${ }^{\mathrm{I} 44}$ and the Philippines ${ }^{\mathrm{I} 45}$ support the use of non-conviction-based confiscation.

Although it has been argued that non-conviction-based confiscation through civil proceedings is a good tool to combat organized crime, ${ }^{\mathrm{I} 46}$ some human rights concerns have been raised simultaneously. Many states have a problem with this type of confiscation, as the lower burden of proof is used and it is up to those affected to prove that the property was not obtained as a result of criminal activities. ${ }^{\mathrm{I} 7}$ In Europe, human rights complaints have also been lodged against various states before the European Court of Human Rights, arguing that non-conviction-based confiscation is criminal in nature and therefore that presumption of innocence (as part of the right to a fair trial) should apply. While this is indeed a convincing argument, it has been held that the purpose of the civil regime is to recover assets illegally possessed, and not to determine one's guilt. ${ }^{148}$ Consequently, non-conviction-based confiscation is generally regarded as not breaching the relevant human rights norms and principles. However, it was simultaneously recognized that sufficient procedural safeguards

\footnotetext{
I38. Phillips v. United Kingdom (200I), Application No.41087/98 at para. 5I.

I39. See, for instance, Adzhigovich v. Russia (2009), Application No. 23202/05, where the European Court held that Russia violated the right to property as there was no clear legal basis for confiscation.

I40. Arvinder SAMBEI, Civil Forfeiture (Confiscation in Rem): Explanatory and Impact Study (Strasbourg: Council of Europe, 2012) at 5.

I4I. Art. I2(9).

142. Proceeds of Crime Act 2002.

I43. Criminal Asset Recovery Order 2012.

I44. Criminal Proceeds (Recovery) Act 2009.

I45. Anti-Money Laundering Act 200 I.

I46. Angela V.M. LEONG, The Disruption of International Organized Crime (Aldershot: Ashgate, 2007) at 77 .

I47. Sambei, supra note I40 at 9.

I48. See Engel v. the Netherlands (1976), Application Nos. 5100/71, 5101/71, 5102/71, 5354/72, and 5370/ 72; Walsh v. United Kingdom (2000), Application No. 33744/96.
} 
(public/open hearings, disclosure of the prosecution's case, and an opportunity to rebut) must be in place. ${ }^{\mathrm{I}}{ }^{9}$ Anything short of these would therefore be regarded as human rights violations.

Finally, punishments for organized crime, with the death penalty in particular, remain a serious concern in the Asia-Pacific. The death penalty is retained for some crimes, most notably drug trafficking. This is true for states including Bangladesh, ${ }^{\mathrm{I}}{ }^{\circ}$ Brunei, ${ }^{\mathrm{I}}{ }^{\mathrm{I}}$ China, ${ }^{152}$ India, ${ }^{153}$ Indonesia, ${ }^{\mathrm{I}}{ }^{15}$ Laos, ${ }^{\mathrm{I} 55}$ Malaysia, ${ }^{156}$ Myanmar, ${ }^{157}$ Pakistan, ${ }^{158}$ Singapore, ${ }^{159}$ Sri Lanka, ${ }^{160}$ Thailand, ${ }^{16 \mathrm{I}}$ and Vietnam. ${ }^{162}$ One does not have to be reminded of the execution of eight drug traffickers in Indonesia in April 2015, which generated strong protests and political tensions among affected states. Although there are ongoing movements towards abolition globally, international human rights law does not technically prohibit the death penalty, as it still allows states to retain this punishment for the most serious crimes. ${ }^{163}$ A problem here is the definition or understanding of "most serious crime". Some states regard drug trafficking as sufficiently serious to merit the death penalty, while many others do not, and there does not appear to be any political will to come to a consensus in the Asia-Pacific, demonstrating the strong force of state sovereignty. It should also be noted that only a handful of states in the Asia-Pacific have ratified the Second Optional Protocol to the International Covenant on Civil and Political Rights, Aiming at the Abolition of the Death Penalty. ${ }^{164}$ Therefore, there is much to be done to facilitate shared understanding of various forms of organized crime and their seriousness in the Asia-Pacific, as stressed above. This, however, is not the reason to discount the value of the international human rights law and movement. Instead, it should be seen as a renewed opportunity to work towards abolition of this punishment.

Another dimension to the death penalty is the principle of non-refoulement. In a landmark case of Soering $v$. United Kingdom (1989), the European Court of Human Rights held that the so-called "death row phenomenon", which might entail, among other things, prolonged mental and physical abuse and suffering, could amount to inhuman and degrading treatment, ${ }^{165}$ and therefore that the applicant could not be

\footnotetext{
I49. Phillips $v$. United Kingdom, supra note $\mathrm{I} 38$ at paras. $43-7$.

I 50. Narcotics Control Act I990, s. I9.

I 5 I. Misuse of Drugs Act 1987 as amended, arts. 3-5, I 5-I6.

I 52. Criminal Law of the People's Republic of China I997 as amended, art. 347.

I 53. Narcotic Drugs and Psychotropic Substances Act 1987, art. 3 IA.

I 54. Law on Psychotropic Substances I997, art. 59.

I 5. Penal Law I990 as amended in 2005 , art. I46.

I 56. Dangerous Drugs Act 1952 as amended, art. $39 \mathrm{~B}$.

I 57. Narcotic Drugs and Psychotropic Substances Act I993, art. 20.

I 5. Control of Narcotic Substances Act 1997, ss. 6-9.

I 59. Misuse of Drugs Act 1973 as amended, ss. I 5-33.

I60. Poisons, Opium and Dangerous Drugs (Amendment) Act I984, s. 5.

I6I. Narcotics Act 1979 as amended, s. 65.

I62. Penal Code I999 as amended, arts. I93, I94.

I63. ICCPR, art. 6(2).

I64. I 5 December I989, I642 U.N.T.S. 4I4 (entered into force I I July I99I). As of May 201 5, these states are Australia, Mongolia, Nepal, New Zealand, the Philippines, and Timor-Leste.

I65. Application No. I4038/88.
} 
extradited. The UN Human Rights Committee also expressed a similar opinion. ${ }^{\mathrm{I} 66}$ Moreover, those states which have abolished the death penalty are to refrain from returning individuals to others which still retain this punishment. ${ }^{167}$ While these are good decisions from a human rights perspective, one practical implication of non-refoulement in this context is that it may make international law enforcement co-operation, such as extradition and mutual legal assistance, difficult, as requested states may not hand over criminals if there is a risk of them receiving the death penalty in requesting states. Interestingly, Australia, ${ }^{168}$ the Cook Islands, ${ }^{169} \mathrm{Fiji}^{170}$ Hong Kong, ${ }^{\mathrm{I} 7 \mathrm{I}} \mathrm{Palau}^{\mathrm{I72}}$ Samoa, ${ }^{\mathrm{I} 73}$ and Vanuatu ${ }^{\mathrm{I74}}$ can refuse extradition or mutual legal assistance in criminal matters for this reason. Bilateral extradition treaties, including those between South Korea and India/the Philippines/Thailand/Vietnam, as well as those between Thailand and Malaysia/the Philippines, also provide for discretionary refusal of extradition. ${ }^{175}$ In addition, other states refuse extradition as a matter of practice. Japan and Mongolia, for instance, can refuse extradition if requesting states impose the death penalty for corruption-related cases. ${ }^{176}$

One way to mitigate this difficulty and diffuse political tensions, while simultaneously maintaining the spirit of human rights and international co-operation, is to rely on aut dedere aut judicare, a well-established principle under national and international law. Simply put, if a state refuses extradition, then that state should bring prosecution in its jurisdiction instead. Interestingly, some states were in favour of including this principle in cases involving the death penalty during the drafting stage of the UNTOC, but an explicit reference was not made in the end. ${ }^{177}$ However, Articles I 5 and 16 provide for this in the broad context, and similar provisions exist in other treaties such as the 1988 Narcotics Convention ${ }^{178}$ and the United Nations Convention Against Corruption. ${ }^{179}$ Although states which still retain the death penalty may not be entirely happy, aut dedere aut judicare is a sensible alternative as it ensures that perpetrators of organized crime are punished one way or another. It must be noted, however, that the nature of obligation under this principle varies depending on the nationalities of perpetrators. Under the said Articles of the UNTOC, prosecution is

I66. Maksudov and Rakhimov v. Kyrgyzstan, Communication No. I46I, I462, I476, \& I477/2006, CCPR/ $\mathrm{C} / 93 / \mathrm{D} / \mathrm{I} 46 \mathrm{I}, \mathrm{I} 462, \mathrm{I} 4768 \mathrm{I}_{4} 77 / 2006$ at para I 2.6.

I67. Judge v. Canada, Communication No. 829/1998, CCPR/C/78/D/829/1998 at para. I0.4; G.T. v. Australia, Communication No. 706/1996, CCPR/C/61/D/706/1996 at paras. 8.2, 8.3; Kwok Yin Fong $v$. Australia, Communication No. I442/2005, CCPR/C/97/D/I442/2005 at para. 9.4.

I68. Extradition Act I988, s. I 5B; Mutual Assistance in Criminal Matters Act I987, s. 8(1A).

169. Extradition Act 2003, s. I9.

I70. Extradition Act I977, s. II(4).

I7I. Mutual Assistance in Criminal Matters Ordinance 1997, s. 5(3).

172. Extradition and Transfer Act 200I, s. 6.

I73. Extradition Act I974, s. I(4).

I74. Extradition Act 2003, s. I7(2)(e).

I75. $\mathrm{ADB}$ and OECD, supra note 77 at 39.

I76. Ibid., 58 .

I77. Travaux Préparatoires, supra note 23 at I 49.

I78. Arts. 4 (Jurisdiction) and 6 (Extradition).

I 79. 3 I October 2003, 2349 U.N.T.S. 4I (entered into force I 2 December 2005), arts. 42 (Jurisdiction) and 44 (Extradition). 
mandatory if a state does not extradite its own nationals. However, the obligation is weak in relation to foreign nationals as the term "may" suggests. ${ }^{\text {I80 }}$

Another way is to fully observe and implement assurances that one would not receive the death penalty. Some states in the Asia-Pacific region indeed facilitate extradition or mutual legal assistance if clear assurances are given, although the designated authorities to give such assurances vary. In Indonesia, assurances must be given by the highest judicial authority of a requesting state, whereas Hong Kong and Japan merely require a statement from the central authority and a consular/ diplomatic representative. ${ }^{\text {I I }}$ Giving assurances is controversial, as its effectiveness is not certain in many cases. ${ }^{182}$ In order to avoid violations of human rights, it has been held, among other things, that the reliability of assurances must be assessed and that there should be an effective mechanism to monitor and enforce these assurances. ${ }^{183}$ If all states in the Asia-Pacific can observe these and other relevant principles, then it would become much easier to promote harmonization and mutual trust/recognition, while at the same time respecting the human rights of perpetrators of transnational organized crime. However, mutual recognition would also mean that those states which do not impose the death penalty must respect others which do. Ironically, despite diplomatic/political protests against this punishment, mutual recognition is observed in practice as states generally respect sovereignty and do not directly interfere with the domestic legal processes of others. The Indonesian incident noted above affirms this.

Despite this current picture, it is encouraging that the attitudes of states towards the death penalty are changing, albeit slowly, compared to the past. It was noted by Amnesty International in 2014 that a half of all states in the Asia-Pacific have abolished the death penalty. ${ }^{184}$ Fiji did this in February 2015 for all crimes, in line with the recommendations made by the UN Human Rights Council during the Universal Periodic Review. ${ }^{\mathrm{I} 85}$ Mongolia is also in the process of amending its domestic legislation to abolish this punishment. ${ }^{186}$ The number of states carrying out executions also seems to be steadily declining. In India, for instance, the Supreme Court commuted the sentence for fifteen people because of delays in processing mercy petitions by the President, ${ }^{187}$ and the Narcotic Drugs and Psychoactive Substances Act I985 was amended to change the mandatory death penalty to an optional one. ${ }^{\mathrm{I} 88}$ In Myanmar, all death sentences were replaced by life

\footnotetext{
I 8 O. The same language is adopted in other treaties.

I 8 I. $\mathrm{ADB}$ and OECD, supra note 77 at 58.

I82. International Organisation for Migration, Information Note on the Principle of Non-Refoulement (Geneva: International Organisation for Migration, 2014) at 8.

I83. Maksudov and Rakhnimov v. Kyrgyzstan, supra note 166 at para. I 2; Alzery v. Sweden, Communication No. I4I 6/2005, CCPR/C/88/D/I 4I 6/2005 at para. I I. See also Othman v. the United Kingdom (20I2), Application No. 8I39/09 at para. I88-9; Extension of Precautionary Measures (N. 259/02) Regarding Detainees in Guantánamo Bay, Cuba (2005) by the Inter-American Commission on Human Rights.

I84. Amnesty International, Death Penalty and Executions 2015, ACT/50/00I/20I 5 at 37.

I 8 . Ibid., at $3 \mathrm{I}$.

I86. Ibid., at $4 \mathrm{I}$.

I 87. Shatrughan Chauhan \& Anr v. Union of India \& Ors, (2014) I SCC I.

I88. Amnesty International, supra note I 84 at 32 .
} 
imprisonment, ${ }^{\mathrm{I} 89}$ and South Korea has been suspending executions in recognition of the ongoing international human rights discourse and movement. ${ }^{190}$ Although there is still a long way to go in abolishing the death penalty in the Asia-Pacific, these examples also show that the international human rights law and movement have played, and continue to play, an important role in achieving this goal. Therefore, it once again seems reasonable to conclude that international law does matter in this region.

\section{CONCLUSION}

This paper has examined the key benefits of international law on transnational organized crime to enhance domestic and regional actions, with a particular focus on the UNTOC, as well as international human rights law in protecting the human rights of the victims and perpetrators of organized crime. It has been shown that, compared to other regions, states in the Asia-Pacific are more reluctant to observe and implement core principles such as the harmonization of domestic criminal laws and procedures and mutual recognition. The protection of human rights also raises serious concerns in some areas. Consequently, the desired effects or impacts of the relevant branches of international law have not yet been fully realized in the Asia-Pacific.

Nevertheless, it is premature to dismiss the value of international law in combating transnational organized crime, as it has also been shown that it is making tangible differences in various areas, and that it is possible to find some common ground. While it is important to respect political, legal, cultural, and social differences among states in the Asia-Pacific, strict adherence to state sovereignty is not constructive, given the transnational and sophisticated nature of transnational organized crime. While the usefulness of bilateral agreements/arrangements should be recognized, it has also been argued throughout this paper that multilateral approaches are even more beneficial. To this end, ratification and/or implementation of the UNTOC are a step in the right direction. Alternatively, if states prefer a regional approach, then they could bring forward regional treaties on various aspects of law enforcement co-operation, which sufficiently reflect the relevant international standards as represented by the UNTOC and apply to all states in the Asia-Pacific. The regional organizations such as ASEAN and the SAARC should also play a more active role in the fight against transnational organized crime in order to enhance solidarity and mutual trust in the region. The time is therefore ripe for states in the Asia-Pacific to recognize the value of international law and devise a more coherent and effective strategy individually and collectively.

I89. Ibid., at 4I.

I90. Sangmin BAE, "South Korea's De Fact Abolition of the Death Penalty" (2009) 82 Pacific Affairs 407. 